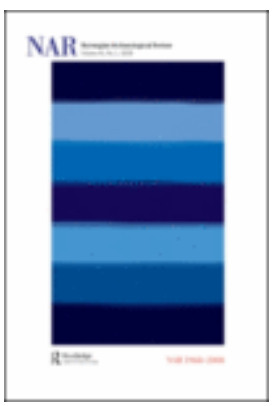

\title{
The heritage of war and the discourse of sustainability
}

\begin{tabular}{|c|c|}
\hline Journal: & Norwegian Archaeological Review \\
\hline Manuscript ID & SARC-2019-0008.R1 \\
\hline Manuscript Type: & Article \\
\hline $\begin{array}{r}\text { Date Submitted by the } \\
\text { Author: }\end{array}$ & 19-Sep-2019 \\
\hline Complete List of Authors: & $\begin{array}{l}\text { Figenschau, Ingar; UiT Arctic University of Norway, Department of } \\
\text { archaeology, history, religious studies and theology }\end{array}$ \\
\hline Keywords: & $\begin{array}{l}\text { Sustainability, Heritage, WWII, PoW-camps, The Lyngen Festung, } \\
\text { Things, Entangled presence, Contemporary Archaeology }\end{array}$ \\
\hline
\end{tabular}

\section{SCHOLARONE \\ Manuscripts}




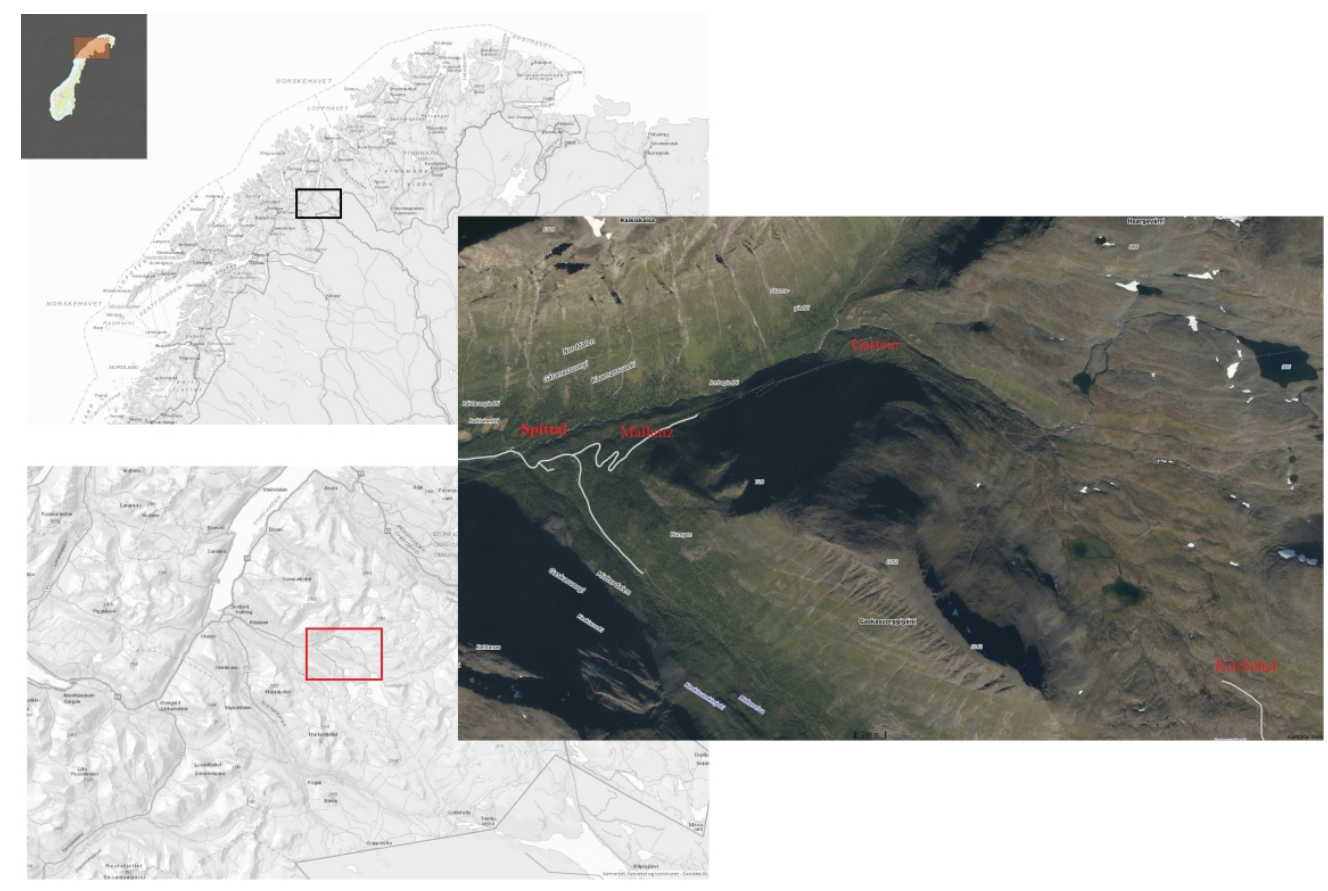

Figure 1: Norddalen, Northern Norway. Part of the Lyngen Festung. $254 \times 169 \mathrm{~mm}(300 \times 300 \mathrm{DPI})$ 


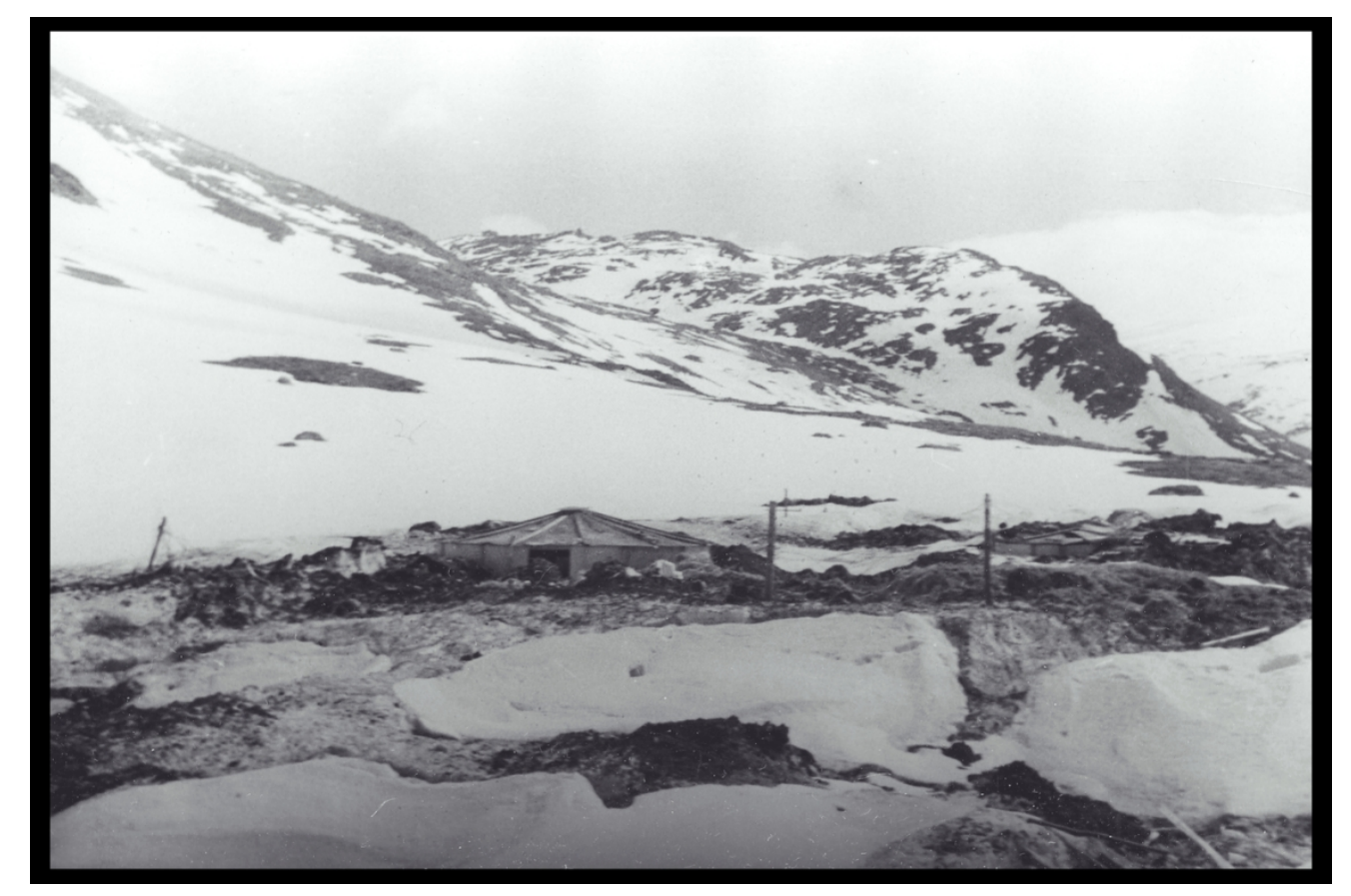

Figure 2: Kitzbühel, June 1945. A single Finnenzelte still stands inside the POW-camp. Photo: Bjørn Winsnes/Narviksenteret.

$115 \times 76 \mathrm{~mm}(300 \times 300 \mathrm{DPI})$ 


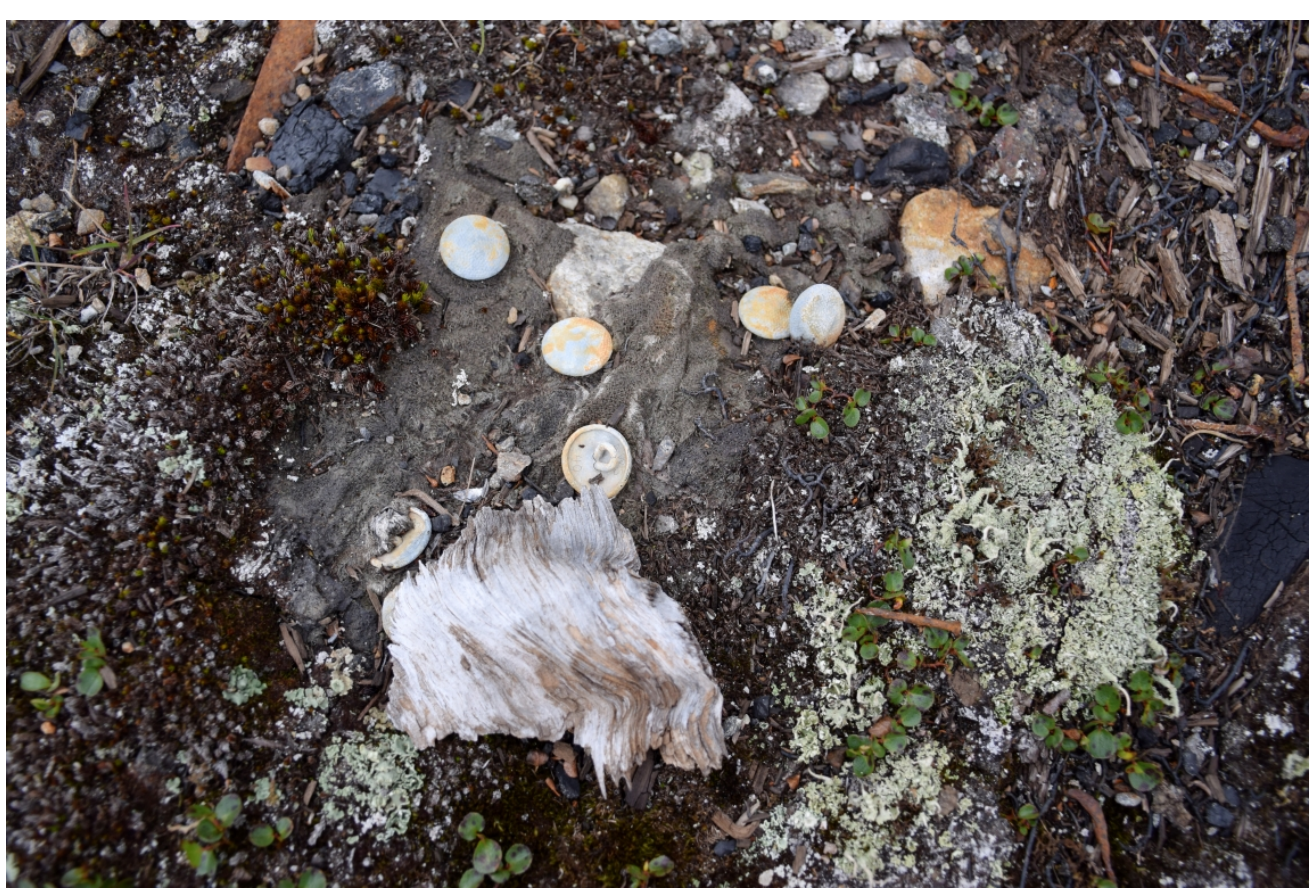

Figure 3: Entangled presence: coke, rusty nails, reindeer lichen, wood, moss, iron, heather and buttons, some still attached to a German uniform. Photo: Ingar Figenschau

$508 \times 338 \mathrm{~mm}(300 \times 300 \mathrm{DPI})$ 


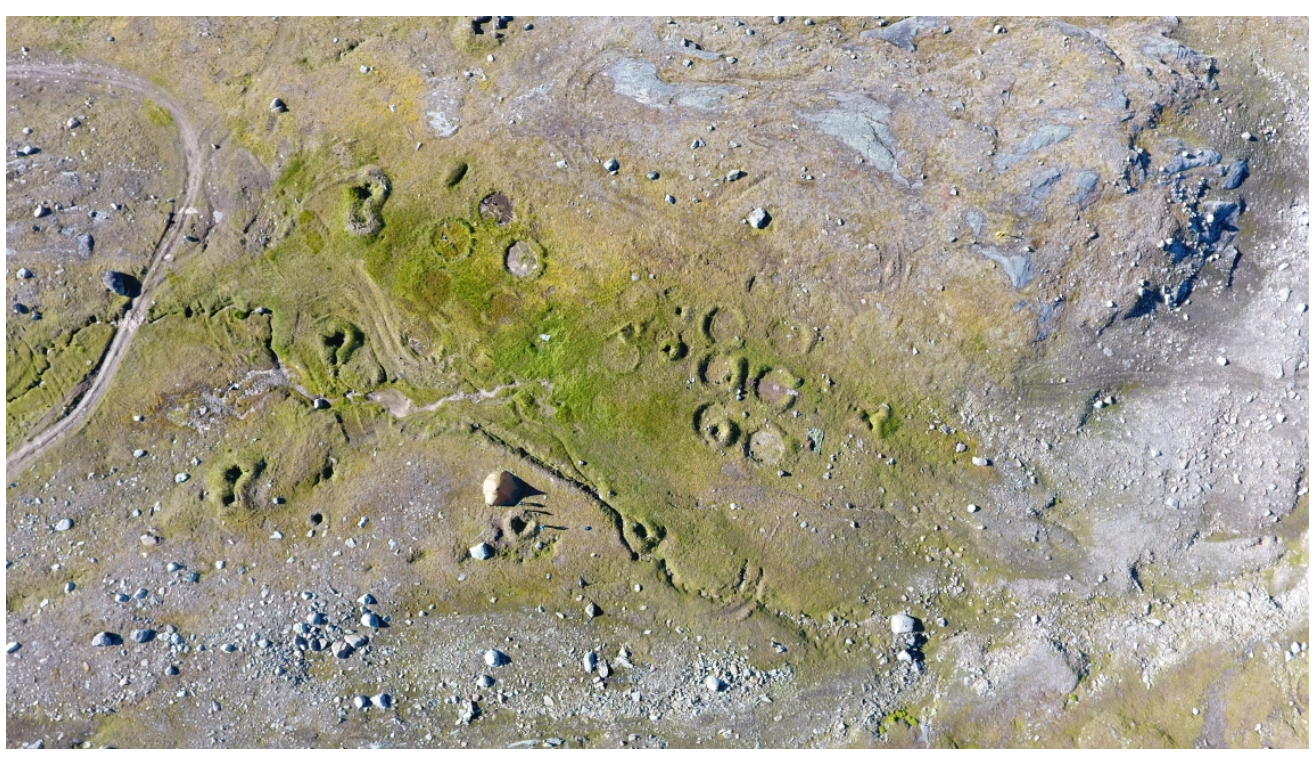

Figure 4: Figure 4: POW-camp Kitzbühel, august 2016. The remains of the tents can be seen as circular structures. Photo: Ingar Figenschau.

$338 \times 190 \mathrm{~mm}(300 \times 300$ DPI $)$ 


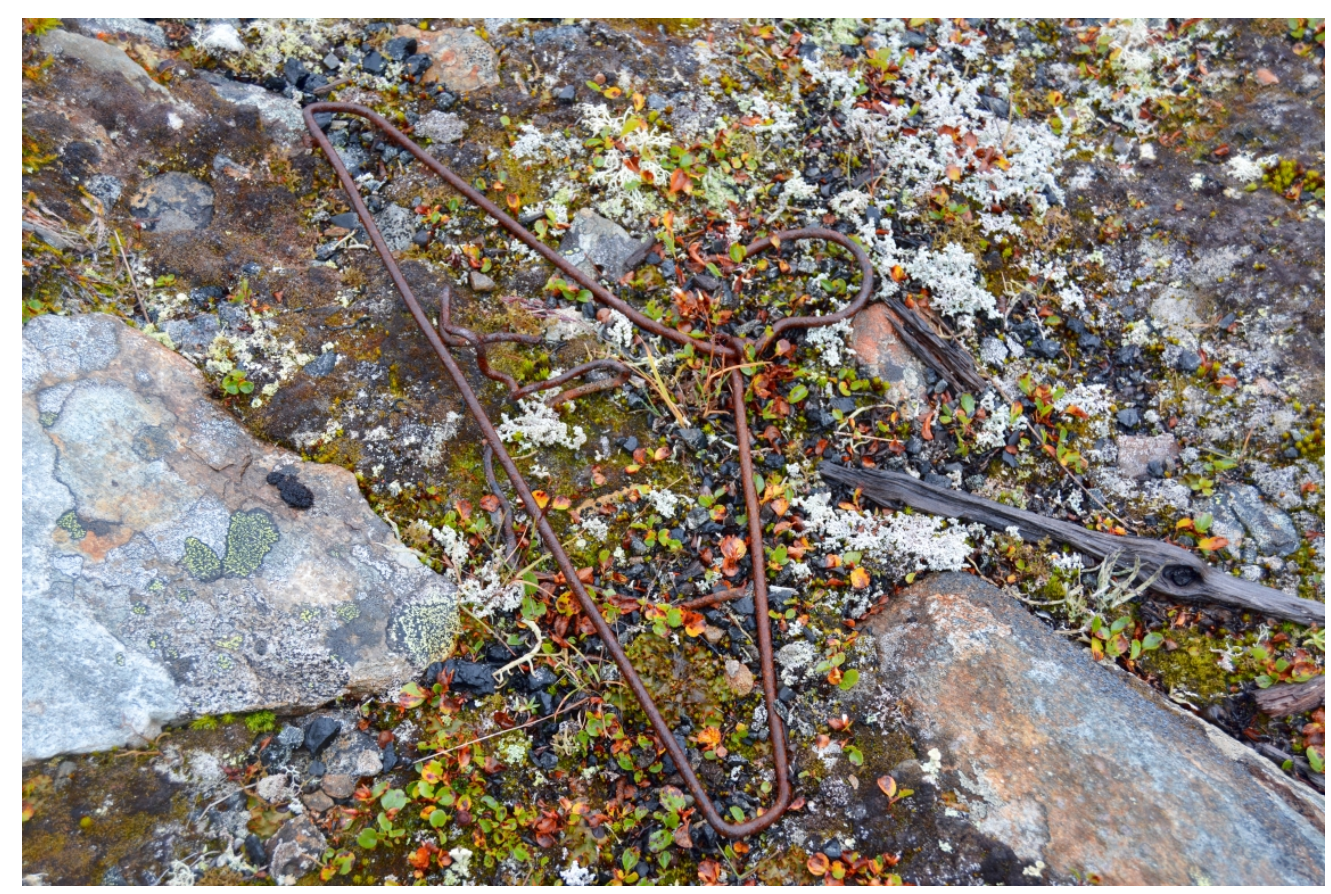

Figure 5: A humble imprint of war. Photo: Ingar Figenschau. $508 \times 338 \mathrm{~mm}(300 \times 300$ DPI $)$ 


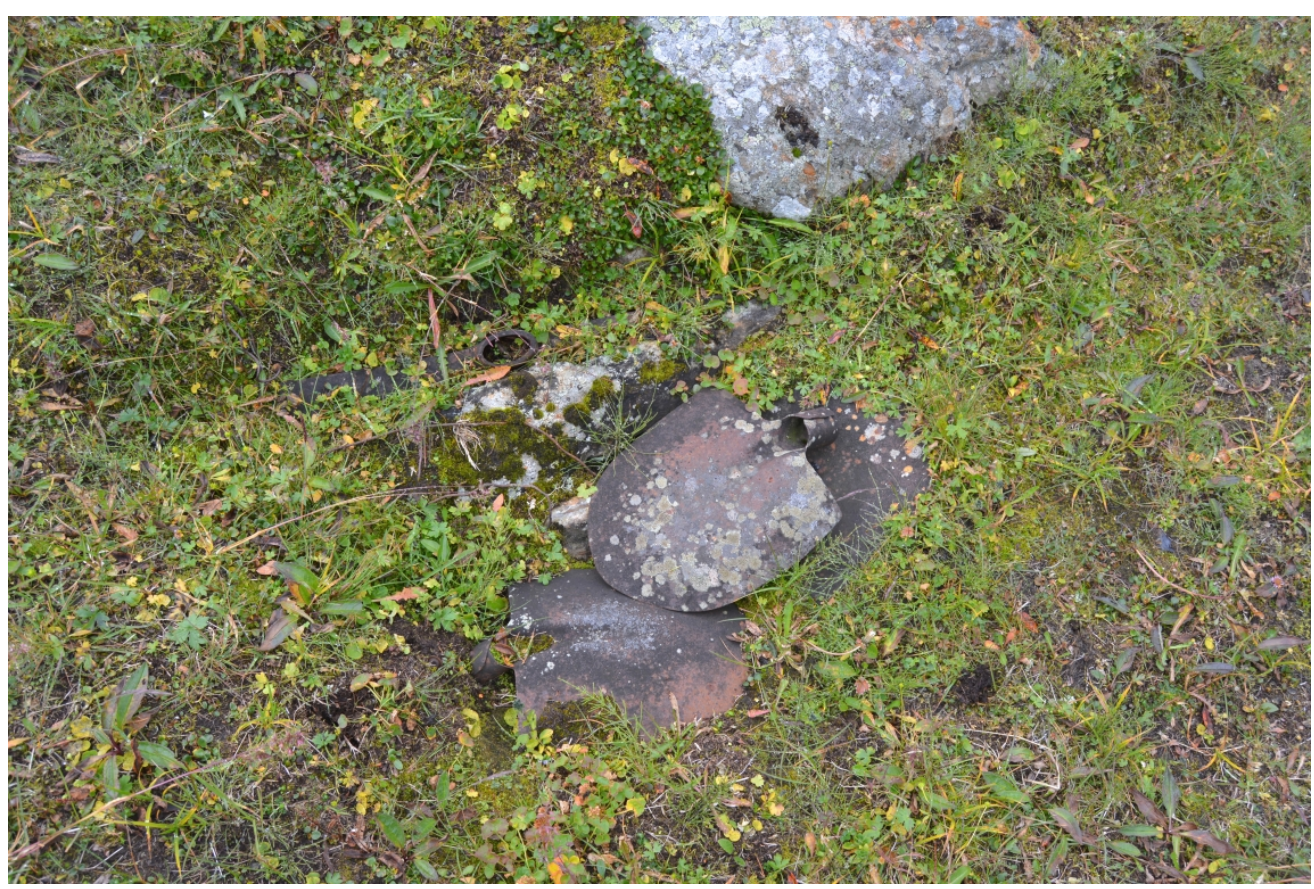

Figure 6: Everyday tools, everyday atrocities. The tools of the Lyngen Festung. Photo: Ingar Figenschau. $508 \times 338 \mathrm{~mm}(300 \times 300 \mathrm{DPI})$ 


\title{
ARTICLE \\ The heritage of war and the discourse of sustainability
}

\author{
INGAR FIGENSCHAU
}

At bottom of page: Ingar Figenschau, Department of Archaeology, History and Religious

Studies, The Arctic University of Norway, Tromsø, Norway. Email: ingar.figenschau@uit.no

\begin{abstract}
$<$ Abstract $>$
Since the concept of sustainability (or sustainable development) became famous through its adoption in the UN's report, 'Our Common Future' in 1987, it has travelled widely to become a global and omnipresent key concept also in the field of heritage. The inclusion into this field was facilitated by the understanding of heritage as resource, which has become the norm within cultural heritage management discourses and strategies. This understanding is increasingly sustained by an associated vocabulary of concepts that promote cultural heritage sites as economically and socio-politically beneficial, emphasising their value as resources for us. This paper explores what happens when this conceptual repertoire of resource thinking is applied to WWII Wehrmacht sites in northern Norway, a heritage that previously has been othered and excluded. How does it impact on the understanding of this particular heritage and how may it be challenged and transformed through encounters with an unruly heritage that potentially defies and distances such conceptualisation?
\end{abstract}

Keywords: Sustainability, heritage, WWII, POW camps, The Lyngen Festung, things, entangled presence

\section{INTRODUCTION}

Fueled by concerns over an ever-growing economic, demographic and technological development, the concept of sustainability became famous through its adoption in the UN's report 'Our Common Future' in 1987 (Brattli 2009, p. 29). Defined here as 'development that meets the needs of the present without compromising the ability of future generations to meet their own needs' (WCED 1987), the concept started out as an environmental one, but has since travelled widely to become a global and omnipresent key concept (Albert 2015, p. 11), also in the field of cultural heritage. Its inclusion there was aided by the long-held 
understanding of heritage as resource, which thus already grounded strategies for protection and conservation (Brattli 2009, p. 25), as tellingly reflected in its twin concept of 'cultural resource management'.

Today sustainability has become close to a mantra within cultural heritage management discourses and strategies. What is equally conspicuous is how heritage discourses are increasingly prescribed and permeated by generalising and circumstantial notions and concepts that define and promote sites and monuments as tools for commemorating and securing a desired past. In more general terms, what we see is a widespread use of what may be termed conceptual metaphors (Moore 2004), which, apart from sustainability, include notions such as resource, cultural property, development, capital, value, and value creation. This is a conceptualisation that leans heavily towards utility and prescribes and promotes cultural heritage as economically and socio-politically beneficial, emphasising - first and foremost - its value as resource for us (cf. Albert 2015, p. 13). It is a vocabulary sustained and naturalised by contemporary political and moral interests, where the past is primarily interesting as a provider of cultural goods for the present and the future (Eriksen 2014, p. 142, 147).

The proliferation and normalisation of a certain way of conceptualising heritage as resource forms the basis of my interest in the sustainability concept. Being coined to designate a development that was ecologically, economically and socially balanced and thus secured the needs of future generations, the concept has taken on its own life conquering areas where its original meaning of environmental protection seems only vaguely relevant. One such area is what variously has been termed difficult, dark or painful heritage, which constitutes the empirical focus of this paper. More specifically, this paper explores what happens when this concept and its associated vocabulary is applied to, and, in fact, used as a way to enhance the status of heritage which previously has been 'othered' and excluded. In my case, this heritage is WWII Wehrmacht sites in Norway, which recently have been assessed as eligible for formal and legal protection and preservation as heritage.

In general terms, the aim of this paper is to investigate how the widespread use of concepts such as sustainability, resource, and value creation impacts on the understanding of heritage. More specifically, my case study focuses on how sustainability is understood and conceptualised within the 'authorised heritage discourse' (AHD) in relation to WW2 heritage 
in Norway. According to Smith (2006, p. 29), the characteristic of the AHD is the emphasis on aesthetically positive and pleasing things, landscapes and sites that must be preserved and protected in order to secure the identity and 'education' of future generations. In Norway, The Directorate for Cultural Heritage and county authorities represent what I associate with the AHD and in this text, I will look more closely at their statements against a specific WW2 archaeological material.

\section{[Figure 1 near here]}

\section{THE LYNGEN FESTUNG: FORTIFICATIONS AND RUINATION}

The case considered in this paper is the POW camps in Norddalen in the Lyngen Fjord area, northern Norway. These were established as part of the last built German defence line in the north, the Lyngen Festung. The building of the Lyngen Festung started in November 1944 and was motivated by events that took place a month earlier and 480 kilometers to the east, at the Eismeer front and more specifically the in Litza Valley on the Kola Peninsula, Russia. After three years of frozen trench warfare resulting from an unsuccessful attempt to invade Soviet from the north, German forces finally withdrew after a massive Red Army offensive starting 7 October 1944 (Jaklin 2006, p. 267). The German withdrawal was nicknamed 'Operation Nordlicht', and happened on three widely dispersed fronts, retreating through Finland and Finnmark, Norway (Mann and Jörgensen 2016, p. 175-176, 185, Seitsonen 2018, p. 37, 53). In their retreat the forces evacuated local people and utilised the scorched earth tactic, preventing the anticipated advancing Soviet troops any benefits from local infrastructure and people (Hunt 2014). The Lyngen Festung was, on direct orders from Berlin, to be initiated in the late fall 1944 and to be completed on 1 May 1945 and was planned as the last ultimate defence against the Red Army at the north front.

\section{[Figure 2 near here]}

The German forces brought along around 10,000 Soviet prisoners of war that were forced to build the new defence line. Much of the slave labour took place under extremely difficult and tough conditions, often in high mountain areas, during the cold, dark autumn and winter months of 1944-1945. That, combined with terrible conditions in the POW camps, poor clothing and constant abuse, resulted in a high death rate among the prisoners (Soleim 2009, p. 119, Lund, 2014 [1982], p. 71). Camp accommodation consisted mainly of thin-walled 
plywood tents, so-called 'Finnenzelte', a type widely used by the German army. With a diameter of 5.5 meters and a maximum height of 2.1 meters, they were initially designed to accommodate up to 20 people (US-Army 1943, p. 75-79, Pool 2016, p. 177, Seitsonen et al. 2017, p. 11). These were made of prefabricated components that were easy to transport and assemble but gave poor isolation in this climate (Arneberg 1993, p. 64, 181). In Kitzbühel, 800 meters above sea level, winter temperatures can reach minus 30 degrees Celsius.

Immediately after the war, in the summer of 1945, two of the POW camps, Mallnitz and Kitzbühel, were investigated by a war crime commission following advice from surviving prisoners. In Mallnitz, the conditions proved particularly bad, as the prisoners there had to settle for sod-walled cabins covered with twigs. They slept on beds put together by chicken wire without any kind of mattress. Such a cabin, with a surface area of just 30 square meters, could accommodate up to 70 prisoners (Lund 2014 [1982], p. 72). Mallnitz eventually became an extinction camp where weak and sick prisoners were sent to die. Interrogation of surviving prisoners revealed stories of executions, cannibalism as well as torture. During the investigations, the commission uncovered four mass graves with 143 corpses. Of these, 81 had died of hunger and typhus, 54 had been shot, eight had been mistreated to death, and three showed clear signs of cannibalism (Fjermeros 2013, p. 70-71, Albrigtsen 2014, p. 104-111, Hunt 2014, p. 154-172, Jenney 2014 [1945], p. 146-155, Lund 2014 [1982], p. 76, Hesjedal and Andreassen 2015, p. 11). In Kitzbühel, six single graves were discovered, while we know little about the conditions in the other camps in the area (Hesjedal and Andreassen 2015, p. 122).

Apart from the immediate investigations of the war crime commission in 1945, the remnants of POW camps in Norddalen received little attention in the post-war period. As remains of a devastating war, where many prisoners were executed or starved to death, the camps represented a legacy that no one would remember or care for. They were even actively forgotten from the official records due to the changed political climate during the Cold War era and because of the difficult and negative content. For a long time, the historical accounts were the last echo of the war, but during the 2000s, the physical traces of the war started to be incorporated in the cultural heritage discourse. War remains achieved an increasing interest from the official cultural heritage management in Norway.

\section{BECOMING HERITAGE}


It was the rather unlikely event of a high-voltage power line development that brought the POW camps in Norddalen to attention again. Rediscovered as part of an archaeological survey carried out in 2010 and 2015 as part of the development (Drageset et al. 2010, Hesjedal and Andreassen 2015), the sites became included in a heritage management proposal for the area. At that time war remains were given a growing public recognition in Norway. Sites from WWII received a particular emphasis in 2015, as part of national protection strategy of the Norwegian Directorate for Cultural Heritage (Directorate for Cultural Heritage 2015a, p. 3). The reasons for this were, among other things, that many of these are threatened and exposed (Directorate for Cultural Heritage 2015b, p. 6), and argued to be important for local and national history and identity. Thus, in order to be appropriate for this, action had to be taken to record, reconstruct and disseminate representative sites (Directorate for Cultural Heritage 2015 c, p. 5). This also had consequences for the war heritage dealt with here.

According to the Norwegian Cultural Heritage Act, cultural heritage older than 1537 is automatically protected (the year 1917 applies for Sámi cultural heritage). Since this obviously does not count for a range of heritage, like the WW2 remains dealt with here, protection based on individual assessment can be implemented. This requires that the cultural heritage in question has a special national or international value (Kahn 2007, p. 254), and this asset was emphasised also for the protection of WW2 sites. In the course of 2016, a conservation proposal pursuant to section 22a of the Norwegian Cultural Heritage Act was developed for the Norddalen area, including the POW camps Spittal, Mallnitz, Gastein and Kitzbühel. Archaeologists from Troms County had, as mentioned, already surveyed and recorded the sites (Drageset et al. 2010, Hesjedal and Andreassen 2015), and further investigations were conducted in Spittal and Kitzbühel in 2016 and 2017 as part of my $\mathrm{PhD}$ research. The surveys consisted of archaeological registration and excavation in both Spittal and Kitzbühel.

The protection plan emphasised the area's strategic military importance, in which both the Lyngen Festung and the subsequently built Cold War/NATO Frøy Line relied on ${ }^{1}$. The many facilities are seen as reflecting a comprehensive, long-term military strategic planning and are argued to be of national and international value. Regarding protection, several of the facilities were recommended to be kept in a controlled state of dilapidation with those who possibly posed a danger to animals and people required to be secured. It was furthermore suggested that some sites representing high pedagogical value were restored and/or made accessible to 
the public. The protection plan was, however, put aside. Due to changed international security policy conditions, the area was re-mobilised in 2018 and regained its military significance as an active combat facility. At the time of writing, it appears that the area's long-term military strategic significance counts more than the heritage speaking to that very same importance. Apart from cancelling the protection, one consequence is that heritage documents that were previously public are now classified. Thus, at the end of the day, the importance of cultural heritage as a provider of cultural goods for the present and the future was overridden by another discourse - security policy.

\section{[Figure 3 near here]}

Today the remains of the Norddalen POW camps are still visible in this northern landscape, preserved in their own natural mode. Objects and structures have slowly grown into and become camouflaged by the environment, creating conglomerates of things and nature, which may not comply well with the common image of cultural heritage as something cleansed and maintained. Although the war heritage in Norddalen ended up not being protected, it is nevertheless interesting to see how these cultural heritages can be understood from an authorised heritage discourse perspective. Encountering their dynamic and extremely entangled presence, it feels pertinent to ask: To what extent could these fragmented leftovers of a painful past — overgrown remains of plywood tents, rusty tin cans, broken helmets, barbed wire, smashed bottles and dry-walled structures have complied with a new articulation as official and valued heritage, and, where their significance is argued through the rhetoric of sustainability and other concept metaphors? What, then, would have happened to their difference, integrity and 'ownness'? This issue became apparent in my own archaeological study of the prison camps in Norddalen and it was accentuated by the ongoing discourse of protection. POW camps, however, are more than just an example of the problem with the rhetoric of heritage sustainability; they may put the very justification of this rhetoric to a test.

\section{SUSTAINABILITY AND MANAGEMENT}

The process concerning these WW2 remains is illustrative for how the Directorate for Cultural Heritage thinks and articulates heritage and protection. The main plot in their story is that the war heritage must be 'saved' from modern threats as they have a particularly important significance for both local and national history and identity, and thus constitute an important social and economic resource to be preserved - implicitly for future generations. 
Strangely, it seems that the remains of war are not factual cultural heritage prior to being documented, reconstructed and disseminated - actions that involve both ethical and practical problems. Although several of the sites are argued to be in a state of controlled decay, at least according to the county authority, this hardly affects the Cultural Heritage Directorate's initiatives. There seems to be a conflict or gap between the materiality and trajectories of the war remains themselves, on the one hand, and the authorised heritage discourse emphasising sustainable development, valuation, economic angles and active protection, on the other. What is meant by the concept of sustainability in cultural heritage anyway? In this specific case, a concept of sustainability emerges, but where does this concept come from, and is it clearly defined and expressed?

Over several decades, UNESCO has pursued its heritage ambitions with several conventions and action plans regarding sustainable development for 'our future'. As Marie-Theres Albert (2015, p. 12), has pointed out, the goals and conditions for sustainable World Heritage management were already expressed in the preamble to the UNESCO convention of 1972. This was further clarified in the Strategic Action Plan for the Conventions implementation (UNESCO, 2011, p. 4), where heritage is identified as a 'driver for sustainable development' (Albert 2015, p. 13). Moreover, UNESCO has noted that cultural and natural heritage is increasingly threatened by human and non-human factors and that the international community must secure and preserve the common cultural heritage as part of the world heritage of humanity (UNESCO 1972, p. 1). Thus, for more than 40 years, UNESCO has globalised a set of principles of sustainable development that in many ways rely on the Janusfaced image of threats and promises for the future - a concept-future used to govern present strategies (Baptista 2014, p. 364) - and which become defined as a global success (Bandarin 2015, p. 35).

Also, in Norway, the concept of sustainability has been actively applied to designate strategies and goals of cultural heritage management. High-level institutional processes form an important background for this. In 1973, the responsibility for cultural heritage management and the Cultural Heritage Act was transferred from the Ministry of Church and Education to the newly established Ministry of Environment (Gaukstad and Holme 2001, p. 138). This created an understanding of cultural heritage protection as an integral part of environmental preservation. It also established an environmentally based political understanding of cultural heritage management, and thus also a politicised approach based on environmental principles 
(Kahn 2001, Nilsen 2003, p. 142-143, 149). This clearly eased the introduction of sustainability as a key concept also in heritage management, and especially from the 1990s and onwards the concept of sustainability became a leitmotiv, as seen in a number of white papers and reports from both the ministry and the Directorate for Cultural Heritage. In its report titled 'Miljøvernpolitikk for en bærekraftig utvikling - Dugnad for framtida' (Environmental Protection for Sustainable Development - Voluntary Work for the Future), the Ministry of the Environment writes, among other things:

The protection and management of cultural heritage and cultural environments is about preserving a resource that is not renewable and constitutes an important part of an overall environmental and resource management. Conceiving cultural heritage as an integral part of the environmental concept and as a dimension of the concept of sustainability helps to put the human, quality of life, and knowledge at the core of environmental work (Ministry of Environment 1997, p. 145, authour's translation).

Much of the same mindset is found in the ministry's white paper 'Leve med kulturminner' (Living with Cultural Heritage):

The aim of actions proposed in this plan is to stop the decay and the loss of valuable cultural heritage. The policy will contribute in such a way that cultural heritage and cultural environments can provide future generations with knowledge and experiences. The government wants cultural heritage to be retained as valuable resources and help create value in living communities (Ministry of Environment 2005, p. 5, authour's translation).

With reference to the UN Action Plan, the white paper concludes: '... respect for cultural diversity is an important prerequisite for sustainable development and to ensure that this development benefits everyone'. And further adds: 'This makes the management of cultural heritage an important tool for a long term and lasting fight against poverty and economic dependence' (Ministry of Environment 2005, p. 92, authour's translation).

In a more recent white paper, 'Fremtid med fotfeste' (A Rooted Future), from 2013, it is further pointed out that cultural heritage: '... give places a unique and distinctive character. They can also be a resource for a positive community and economic development' (Ministry of Environment 2013, p. 5, authour's translation). Based on this, it is argued in the document that Norwegian heritage policy must aim at managing the cultural historical legacy as a longterm cultural and environmental resource base for tomorrow's society. Most importantly, heritage is seen as an important resource for sustainable development, including environmental, social, and economic value creation (Ministry of Environment 2013, p. 42). 
As I have indicated, a consistent trope in these documents is the repeated insistence on heritage-as-resource, where the main objective is to facilitate continued use that activates heritage as an attractive and relevant cultural and economic capital. Interestingly, the use of the concept of sustainability seems to undergo a change along the way to become increasingly more associated with economic value and business development. This is very evident in a recent assessment of the socioeconomic value of cultural and natural heritage - commissioned by the Directorate for Cultural Heritage - aptly named 'Verdien av kulturarv' (The Value of Heritage) (Gierløff et al. 2017). The goal there was to 'visualise the socioeconomic value of cultural heritage and cultural environment, and to show concrete values of them in Norway' (Gierløff et al. 2017, p. 4, author's translation and emphasis). The reason for this, they furthermore state, is that it is 'appropriate with a good and professionally sound valuation and perceptibility of cultural-historical values, which estimates the value of cultural heritage and cultural environment in money' (Gierløff et al. 2017, p. 4, author's translation). Value creation, protection through use, and sustainable development are all linked to the ongoing rewriting of cultural heritage and cultural environments into becoming also a socio-economic and even commercial enterprise - a cultural economy of heritage. As a consequence, the value of heritage increasingly comes to us through economic prospects and estimates, and the transformation is made feasible through an ongoing conceptual transformation, a new way of speaking and writing about the field, where the sustainability concept has become a key ingredient.

However, despite its prominent position in reports and white papers, remarkably little is said about what sustainability actually is or means. This semantic void clearly makes the concept flexible but also vulnerable to unforeseen uses. For example, it is vastly underemphasised and under-theorised - how much of its current mobilisation in heritage discourses implicitly and explicitly facilitates and legitimates an understanding of heritage as resource, capital, and even commodity. Such a rewrite justifies a management based on contemporary needs and, thus, a use-value or beneficial understanding of both sustainability and cultural heritage. As I will return to below, this mindset is also remarkably present within academia and even critical heritage discourses (e.g. Harrison 2013a, 2015).

Thus, within the cultural heritage sector, the concept of sustainability is no longer a term that is just linked to environmentally based discourses on conservation and protection; there is also an increasingly clear tendency to incorporate ideas about economic proficiency. These ideas 
or meanings are often attached through use, rather than explicit semantics and they are furthermore facilitated and 'normalised' by the concept's positive connotations. The term has long been part of the national heritage management and Norway's AHD, but is also - at least implicitly - integrated in the local municipality's understanding of its war remains in Norddalen. However, is this view compatible with the cultural heritage that is actually there?

\section{BLACK BOXES AND FLOATING CONCEPTS}

Theoretically, how does concepts such as sustainability take on their own lives? As evident from this short overview, the concept of sustainability is widely used in heritage discourses and policies. It has achieved something akin to an honorary status, an acclaimed taken-forgrantedness as 'good', in the new era of environmental awareness. Additionally, it is precisely the uncontested positivity of the sustainability concept that makes it so appealing as a globally circulating term. It has, as Baptista (2014, p. 361-362) has argued, evolved into a universal moral language that speaks to equally universal ethical norms. This also makes it more difficult to critically scrutinise the term and to understand the meaning and definition of it, both because of its broad scope, but also because it is formulated as a common good, as something fundamentally positive and ethically correct. This is very clearly illustrated through an image search on the internet, which unequivocally shows green and positive images that bolster sustainability as good for 'everything' - fighting for equality and against poverty.

Through its immense success as a travelling concept, sustainability has become what Bruno Latour (1987, p. 2-3) may have defined as 'black-boxed'- or, in this context, perhaps 'green boxed' is more in line with the current political climate. The concept is not affected by the things it encounters; to be sustainable implies a one-way direction of thinking about value and significance, where things and natures are never expected to challenge the term in itself. It has become an undisputed matter of fact and a determined point of departure. The increasingly more frequent use of the term within very different academic and political contexts, has helped to establish the concept as inevitable. Along the way, however, it has gradually evolved into a nonspecific and all-inclusive term without any clear content and description. It has been characterised as consistently diffuse (Corvellec 2016), and even meaningless and incomprehensible (Baptista 2014, p. 361). Although it may seem curious that such an ambiguous term has become an omnipresent global category, this may precisely be yet another reason for, as well as consequence of, its success. Sustainability is not just something 
that can be applied to resources, but it can embrace a variety of opinions, values, symbols, definitions and implications - all depending on context and emphasis. Through its many repetitions, and successful travels between academic, political, economic and environmental discourses, sustainability has become a positive modality, which has further led statements and assertions away from the original context of creation, thus making it strong (and slippy) enough to 'survive' in other environments (cf. Latour 1987).

Working from Claude Lévi-Strauss' (1987) concept of floating signifiers (see also Laclau 1990, p. 28, Hult 2017, p. 26-27), Henrietta Moore (2004) has coined the term 'concept metaphors' to denote instances where conceptual and domain-based perceptions act as metaphors without any specific reference or exact definition. They can act as stimulating tools for thought, but can rarely be directly associated with distinct objects or relationships in the world (Moore 2004, p. 73). The concept of sustainability in many ways fulfils such characteristics, where its usefulness lies precisely in the absence of any clear referent or signified. Its frequent and far-ranging travelling and diverse applications are based on the fact that it has a shifting, unspecified and uncommitted attachment to real objects - it asserts an ambiguity that maintains the tension between general argumentation and specific contexts (Moore 2004, p. 74). In other words, sustainability becomes 'useful' in many areas precisely because of the lack of concrete or binding attachment to objects and 'reality'.

\section{IMPRINTS OF WAR: LAGER KITZBÜHEL}

What happens when such a vague and 'black-boxed' concept as sustainability, which in practice, and implicitly, seems to deal with economic and environmental policy principles, is increasingly applied to the Norddalen war heritage by the ministry, the Directorate for Cultural Heritage, as well as county and municipality authorities? To what extent can it be said to care also for the properties and presences of this material, to help manifest its own qualities and difference? Or, are such conceptual metaphors largely a detachment from the remains of war, which through their generalising effect, turn them into non-binding generic phenomena in an ever-increasing anthropocentric heritage context? In other words, what are the consequences of applying the concept of sustainability to the WWII war remains? In order to approach these questions, I return to the POW camps in Norddalen, northern Norway.

In the following, I present some aspects of this heritage from my investigations in Kitzbühel, one of the four POW camps named after Austrian alpine towns, in order to further explore the 
questions raised above. The prison camp is located in Norddalen, an extension of Kitdalen valley innermost in Lyngenfjorden in North Troms, Norway. Kitzbühel is situated at an altitude of 800 meters above sea level, far away from the nearest rural settlements. The landscape is barren with just some sparse vegetation in between the rough, but relatively smooth mountain ridges. At first glance, the landscape looks desolate, but as one moves closer circular structures representing imprints of plywood tents suddenly appear. Walking around in a landscape, that only a moment ago looked deserted, soon reveals an array of things and structures that have inhabited the site ever since the war ceased. Things that hold their own memories that both witness, complement, and disturb the canonised history of war: Glass bottles, footwear, building blocks, tinplate's, barbed wire and dry walls, spades, pickaxes, stoves, pipe hats, coke, window glass, tin cans, oil barrels, china, faience, canned goods, pages from what was once a book, ski bindings, wooden boxes, gas tanks, helmets and other military objects. All still lying on the surface, but partially camouflaged by the ongoing natural conservation and decay.

\section{[Figure 4 near here]}

Kitzbühel is in many ways a battlefield that never experienced a battle, but which still bears the unmistakable imprints of war - a distinctive and different war that perhaps more illustrates its 'banality' and 'everydayness' and therefore also enacts a resistance to the established dramatic narratives. Nature's intrusion is very visible there and the blends are not only between nature and material culture, but also between the familiar and the unfamiliar. In the midst of an area providing accommodation for soldiers and guards, I encountered a metal coat hanger. This single, humble artefact makes an immediate recognition of something normal and ordinary, homely and familiar, but also awakes turmoil just by lying here, next to a POW camp in a cold and barren alpine landscape. An everyday artefact similar to those hanging in our closet today, but which seems utterly odd and out of place here. Yet, it triggers involuntary thoughts and associations, such as the need for maintaining a certain order and decency even under such conditions - to maintain a routine. If possible, the uniform was hung up every night by a Wehrmacht soldier, brushed, cleaned and kept away from the dirty earthen floor. For the soldier, such things could provide a welcome instance of normality in a cold and dark landscape, a momentary escape from the increasing concern over the outcome of a war already too long. Perhaps, also, from the troubling thought that 100 meters away, 
Soviet prisoners froze themselves through the night in poorly isolated plywood tents and lousy clothing.

\section{[Figure 5 near here]}

Equally as affective is the encounter with a collection of spades and pickaxes that are partially overgrown in a small recess just outside the camp. All wooden shafts are gone, as if the point of contact between the tools and the people who once used them have obliterated. The rusty shovels have clear signs of use, and it is difficult to avoid thinking that these were the prisoner's daily working tools - a work that for some became their last chores. They do indeed represent very concrete memories of the prisoners' slave work with roads, shelters and bunkers, work initiated to stop their own comrades in a Red Army that, paradoxically, never undertook the anticipated chase into Norway. One is left wondering about what has been accomplished with these everyday tools, how many kilometres of road they have built, the enormous amounts of rock, earth and snow they have dug away and moved - in the hands of starving prisoners. Although the soldiers and prisoners are long gone, features and things remain as concrete memories of the inhumane wretchedness, the everyday drudgery and what was to become the last fortification of the war on the north front. Today the spades and the pickaxes share their fate as redundant with the metal coat hanger lying exposed nearby. The distance seems short now, but at the end of the war, those 100 meters likely made a huge difference and must have been perceived as insurmountable for the malnourished prisoners.

\section{[Figure 6 near here]}

Encountering these assemblages of things far from the war's main battlegrounds makes the experience of Kitzbühel strangely concrete and personal. It becomes an intimate contact with fragmented objects, which still silently resist that the war is over. They have all survived the acts of war, outlived the soldiers, the prisoners, the ideologies and the great political accounts - they enact the war in its stranded and decayed post-war state. One is struck by the cacophony of ineffable impressions that emerge from the site, from nature and weather, impressions that often are hard to articulate. Still, facing the material in its 'true' habitat reminds one of the details and trivia of war and how much of the war heritage is made up of things, small and large objects, weathered and partly hidden in the landscape (cf. Seitsonen 
2018). In such intimate encounters with objects and place, concepts like sustainability, utility, resource, value and profit creation become utterly irrelevant and meaningless. It is precisely the inherent value of things and the location, its ongoing decay and weathering, which reflects Kitzbühel - which is Kitzbühel. Values that are difficult to translate or convert into sustainable concepts. It is also precisely this inherent value in Kitzbühel that is difficult to combine with 'our right' to create a historical foundation, a transformation of the war remains into identity tools for present and future generations. It is a self-created natural management and conservation, difficult to translate and reconcile with the expectations and concept metaphors of the AHD.

Kitzbühel and the other POW camps in Norddalen continue to convey affective memories of themselves, and even in such an eerie context they also care for those everyday and banal experiences and events that often escape historical consciousness, or are regarded too trivial, irrelevant or too embarrassing to be accounted for (González-Ruibal 2008, p. 260-261, Olsen, 2013 , p. 215). These leftovers of war hardly comply with what we usually associate with heritage sites and monuments. They nevertheless create affects, which, through the combination of their auto-preservation and closeness in time, become very concrete, touching, and thus significant. This is also what causes concerns when they are now facing the possibility of promotion to the category of official cultural heritage - and subjected to generalised and abstracted discourses about sustainability, value creation, and resource management. To what extent are these discourses, this vocabulary and these management strategies able to care for what these ruined things have become, and how they affect us upon encountering them? To what extent will their otherness survive this heritage inclusion?

\section{IMPRINTS OF SUSTAINABLE HERITAGE}

As argued above, the discourse of sustainable heritage as hitherto normalised and globalised justified management based on utility; that is, on a beneficial understanding of heritage, and the past, as resources that should serve our needs. In this way, it appears that the many conventions and documents dealing with cultural heritage and sustainability largely follow the mantra to facilitate our common needs.

This also raises ethical question, both related to nature and origin of this particular heritage, but also, and more generally, with regard to the role of things, heritage itself, within heritage discourses. Since ethical heritage concerns particularly have been voiced in efforts to deal 
with marginalised or difficult pasts, they seem appropriate for the kind of heritage dealt with here. Being articulated as an important means to make up for past errors, to bring to justice what was left unsettled, heritage may offer consolation - and remembering - for present and future generations. It remains to be seen, however, what place such concerns possibly will have in this particular case, and how the painful past represented may be cared for in the heritage discourses embracing it.

The ethical discourses on heritage have mostly been on heritage as a human concern, and firmly grounded in human rights. Likewise, and despite the repeated claims that cultural heritage focuses all too much on things, monuments, and, thus, tangible heritage, there is actually not much about things and objects in the many conventions and policy documents on heritage. The focus is rather on quite intangible issues such as identity, belonging and value, and equally abstracted notions such as development, human resources - and sustainability (Pétursdóttir 2013). In other words, monuments and sites are considered important and of ethical significance, mainly because they acquire value through their enrolment in contemporary socio-political and/or humanist programs and practices. Despite voiced concerns with the material past, things themselves, qua things, have rarely been the objects of concern in ethical debates. In other words, things of the past are valuable, and something to be preserved, primarily because they in one way or the other can be used to serve human interests. It is their use-value that matters, as identity anchors, sources of knowledge, and tourist attractions (Pétursdóttir and Olsen 2014). Things are basically things-for-us, reduced to what Heidegger termed Bestand, that is, where their primary significance is reduced to their value as resource (Heidegger 1977, Introna, 2009). It is not so much things themselves that matter, but what they can do for us.

Indeed, it may be argued that one potentially positive outcome for such 'othered' heritage, as treated here, may be that it achieves acceptance as significant heritage. Becoming a concern for heritage institutions, and addressed by a recognised and endorsed vocabulary, previously othered things and sites are ascribed values that appeal to us (Myrvoll 2012, p. 73). Applying concepts such as sustainability may prove helpful for incorporating difficult and sometimes undesirable cultural heritage, and thus enhance its status as such, a process that in itself seems democratic and promising. Still, yet another serious ethical problem arises if this inclusion becomes conditioned upon subjecting this othered heritage to an abstracted sameness, to ever the same concept of heritage, which can be articulated, debated, protected and promoted 
without much compromises and modifications with respect to the actual material that is embraced. In short, to a discourse that seems void of any curiosity and openness to things' being, how they affect us upon encounter, and takes seriously how they persist, gather and outlive us (Olsen and Pétursdóttir 2016, p. 40).

This is what I fear may be the outcome here if the protection plan is to be re-implemented, and to which existing documents and discourses on Norway's war heritage speak. No matter how one twist and turn it, Kitzbühel, like so many other sites, is preserved as it is due to the absence of human intervention. It is precisely this ecological form of auto-conservation, and the lack of human influence, that has created Kitzbühels unique appearance. The formulated plan for the protection of the cultural heritage, is, however, likely to subject Kitzbühel to a normalisation - to be standardised and adapted to the framework that the AHD adopts with its ever-increasing emphasis on economic incitements.

A nearby related case, just beyond the Finnish border, at Järämä, where the Germans constructed a defence position called Sturmbock-stellung, is worth a brief consideration. Its position is linked to the German presence in Finland and was established to secure the Norwegian ports and was further used in the late autumn of 1944 to prevent the advance of Soviet and Finnish forces following the German retreat to Lyngen. There, a museum was built during the 1990s and parts of the position was restored and reconstructed back to its 'original' form. The museum's presentation has not only removed parts of the original structures through restoration and conservation, but also domesticated and made them 'look good' in order to attract visitors; in other words, adapted them to serve an ambition of value creation.

Part of the Järämä site is a reconstructed site, adjusted to fit a specific contemporary context, whereby a once different and difficult past is reshaped and cleaned in order to facilitate reuse in the present (Figenschau 2016, p. 212). By doing so, however, we risk transforming it into the same ready-made story of value, identity and recourses; we do not meet things in their otherness but in a staged presentation adapted to a particular framework, vocabulary, and trope. Through the restored facilities we can admire the work and strategic military decisions, without having to deal with the memories of broken and redundant things. The site may serve as a model-case for a sustainable approach to WW2 heritage. Järämä attracts tourists and generates money and some jobs, and fits well into the conception of heritage as a beneficial resource, which may very well have some merits. However, comparing this to the experience 
of encountering a Kitzbühel in its 'raw' form of auto-preservation also makes it an exemplary case of the price paid.

\section{A COMMON APPROPRIATE PAST FOR OUR COMMON FUTURE?}

This concern with heritage as a sustainable human resource also characterises critical heritage discourses. Among the most prominent representatives of this field is Rodney Harrison (2013a, p. 590), who asserts that sustainability 'can be defined simply as the capacity to survive and sustain' Due to this capacity, and our will to preserve and create heritage. Harrison (2013a, p. 590) argues that we are facing an accumulation crisis of having too much heritage, and which thus threatens to render it socially and culturally irrelevant. Since objects, monuments and sites are conserved according to certain criteria determined by contemporary culture, they will, according to Harrison, at some point inevitably cease to be relevant or represent values that are no longer considered sustainable or pertinent to contemporary and future societies (Harrison 2013a, p. 580). In order to overcome this, he argues for 'active decision to delist or cease to conserve particular forms of heritage once their significance to contemporary and future societies can no longer be demonstrated' (Harrison 2013a, p. 579, author's emphasis). Importantly, he also claims this as a sustainable strategy: 'In relation to heritage, I suggest the concept of sustainability forces us to question not only the capacities of various objects, places and practices of heritage to persist, but also whether the pasts which they are actively creating in the present could or should endure into the future' (Harrison 2013a, p. 590). Although Harrison actually aims to work out an applicable definition, it is peculiar to note how his entire argument is based on human stewardship and control, conceiving heritage and the past as something we can choose and select, and where the goal seems to be to edit an appropriate past for our present and future needs (see also Harrison 2013b, p. 166-169, 2013a, p. 583, 587, Boccardi, 2015: 95).

Although framed through a very different theoretical reasoning, these arguments share much of the same beneficial understanding of the heritage and the past as featuring in official and state-run heritage policies. As argued by Anne Eriksen, the past is only interesting as a supplier of attractive elements where the historical context is overwritten in order to serve, adapt to, and be defined by the present - 'heritage is a matter of the present and the future' (Eriksen 2014, p. 147). Regardless if cultural heritage is 'disneyfied' or unruly, it is often put in the context of human stewardship. 
Such stewardship regarding remains of war is often in the context of 'dark tourism' or 'difficult heritage', a broad term that links tourism and places of human suffering and death (Seitsonen 2018, p. 20). Although the 'heritageisation' of many of these sites initially is intended for educational purposes, there is a criticism of the ever increasing commercialisation and normalisation, where such places are commodified and turned into commercial and acceptable products, which in the process may create an estrangement and distortion of tragic historical events (e.g. Cole 1999, Lennon and Foley 2004, Young 2009, Light, 2017;). Much of the same wording has been used for the war remains in Norway, where profit, availability and commercialisation are promoted. There are obvious ethical aspects of such an emphasis, but it is also interesting to register how remains of war, "painful heritage', largely are to be facilitated for us - as a reconciliation tools that help us come to terms with a negative past without offending victims, survivors or society in general. For the Norddalen prison camps, this could not only result in manipulation and censorship of the actual material that has survived, but also, as a worst-case scenario, allow for questionable ethical dissemination of the camps - including commercialisation of torture, death, executions, and hunger. For the sake of value creation, the prison camps may become tools for dubious interpretation and presentation of their legacies - an aesthetic taciturnity to make them more manageable and sustainable.

\section{CONCLUSION}

The prison camps in Norddalen will probably never be turned into objects of mass-tourism, as the area is too remote. Perhaps the location and the natural conservation form may counteract active commercialisation and cultural gentrification, but also any active changes aimed at limiting the negative impact on victims, survivors and society, or a form of intentional symbolic amputation, calculated decay, trivialisation or even aestheticizing (cf. MacDonald 2006, Seitsonen 2018). Perhaps it is forgotten, as Samuels (2015, p. 124) writes, that the 'negative', 'dark', 'undesirable' or 'difficult' within heritage is not the sites or events in themselves, but rather for us to handle these ambiguities.

The Norddalen camps are an example of heritage that has survived on its own and nature's premises, without any human stewardship. Following the arguments discussed above, they may have been destroyed, erased, and, indeed, with good reasons, as things selected to forget. However, despite being negative and painful recollections, they stubbornly continued their slumbering afterlife. To a large extent, their preservation was accidental or at least 
unintended. It was the combination of the absence of people, cold climate and a high-altitude location with slow decomposition, as well as cold-war military restrictions, which facilitated their preservation. They were allowed to manage themselves, enact their own 'sustainability', or as I choose to call it, enact their dynamic existence - or just continuance and 'letting be'.

Sustainability has today become a global moral term that advocates presumed universal ideals about how to live our lives. Presented as a positive and democratic condition that will benefit the community, it promises to give people the power to shape their future in line with specific norms and beliefs. The ongoing process of turning these POW camps into official heritage takes place within the framework of such general ethical concerns. Here, protection and dissemination are seen both as a way of correcting earlier ignorance and exclusion, as well as a positive act that will socially and economically benefit the community and the future. In this understanding, sustainability becomes part of a dominant discourse that legitimises and justifies different interventions for 'a common good, for a common future' (Baptista 2014, p. 362). According to the Norwegian Directorate for Cultural Heritage, WWII heritage is important for our identity, for tourism development, and other 'value creative initiatives', at both a national and local level. It therefore recommends that:

Cultural heritage management, and also municipalities, should collaborate with local participants with regard to mapping, disseminating, restoring and fostering economic growth, so that the war remains can be reused and become a cultural, social or economic resource in the municipality (Directorate for Cultural Heritage 2015c, p. 5, author's translation).

Apart from exemplifying how the resource paradigm has become normalised and 'blackboxed' in much current heritage, what is equally conspicuous in these discourses is the absence of the actual heritage in question. Hardly anything is said about the things themselves, their survival and afterlife, which is so well manifested here. Understandable, perhaps - for how can one translate places and things' being into such a beneficial cultural heritage understanding?

The remnants of war in Kitzbühel and the other Norddalen camps have proved their capacity for survival. Through their own affordances and natural entanglements they are proofs of a very concrete and yet dynamic non-anthropocentric heritage management. In addition, what is easily forgotten, is that these things thereby have enacted their inherent capacity for sustainability - their ability to last and endure. This is a genuine sustainability that springs from things themselves taking care of themselves through a dynamic form of auto- 
preservation, and which allows them to be, to change, and to enter into new constellations with other things and natures. The fundamental question is to what extent heritage discourses will pay any attention to this 'object lesson'; allow themselves to be challenged by its concrete suggestions to incorporate material and ecological aspects, and thereby to liberate themselves from an abstracted understanding of both sustainability and cultural heritage itself? Would the cultural heritage sector be able to secede from an ever-increasing anthropocentric discourse, and to greater extent allow things to be - and thereby also to decommission the mantra and populistic slogan of 'heritage-as-resource for our common needs'?

Today, the concept of sustainability has intruded most aspects of our everyday lives. This initially positive 'green boxing', which emphasised environmental concern and the need for human modesty, has, paradoxically, created an arena for an ever-increasing utilitarian approach to our environment, to heritage, and to literally everything. As widely used today, heritage discourses included, the concept of sustainability has become a tool for transforming things into resources, and where their being increasingly is justified upon their ability to serve as resources in the present and the future. The Kitzbühel coat hanger, pick axes and spades provide an alternative to this way of thinking heritage. They are all preserved in their own state of self-preservation not locked to any specific time, not placed in glass cases, or being subjected to any norms of good or bad, or even to heritage law. They have simply endured in this secluded and mostly nonhuman context - subjected to their own and nature's care.

Somewhat paradoxically, due to this care and survival the once unwanted remnants of war have become a 'wanted' heritage, which shows that if there is anything that is certain about the present, it is that it is characterised by rapid changes and a will to absorb that often have resulted in unintended and unwanted outcomes, (Eriksen 2016). Their fate is therefore a timely corrective to the idea of making heritage topical; to subjugate it to what is ever pressing on the socio-political agenda, and to devaluate things 'once their significance to contemporary and future societies can no longer be demonstrated' (Harrison 2013a, p. 579). By being present, they make a plea for the allowance also for things that are broken, boring or banal, those things that are without 'purpose and meaning' and without any immediate prospects for value creation and profit. Thus, perhaps there is also a lesson of patience and 'letting be' to be learned from this sustainable ruined record. 
1. Frøy Line was a defensive position commenced in the early 1980s and it was built due to increasing political turmoil between East and West. Major parts of the defence line were constructed along the German Lyngen Festung. However, even before the Frøy Line were completed, they were classified as outdated by the Norwegian army, and in 2006 the demolition of several installations began (Dalmo 2013). Due to changes in the political situation, all demolition was halted and in 2017 , parts of the facility were reinstated.

\section{REFERENCES}

Albert, M.-T. 2015., Mission and Vision of Sustainability Discourses in Heritage Studies. In: M.-T. Albert, ed. Perceptions of Sustainability in Heritage Studies. Berlin: De Gruyter, 11-19.

Albrigtsen, R., 2014. Krigsår i bilder. Glimt fra Norge 1940-1945, Narvik: Forlaget Kristiansen.

Arneberg, S.T., 1993. Tragedie i Karelen. Norske skijegere i den finske Fortsettelseskrigen 1941-44. Oslo: Grøndahl Dreyer.

Bandarin, F., 2015. Sustainability in the World Heritage Convention: The Making of a Policy Framework. In: M.-T. Albert, ed. Perceptions of Sustainability in Heritage Studies. Berlin: De Grutyer, 35-46.

Baptista, J.A., 2014. The ideology of sustainability and the globalization of a future. Time \& Society, 23 (3), 358-379.

Boccardi, G., 2015. From Mitigation to Adaption: A new Heritage Paradigm for the Anthropocene. In: M.-T. Albert, ed. Perceptions of Sustainability in Heritage Studies. Berlin: De Gruyter, 87-97.

Brattli, T. 2009., Managing the archaeological world cultural heritage: Consensus or rhetoric? Norweagian Archaeological Review, 42 (1), 24-39.

Cole, T., 1999. Selling the Holocaust: From Auschwitz to Schindler; How History is Bought, Packaged, and Sold, New York: Routledge, Taylor \& Francis Group.

Corvellec, H., 2016. Sustainability objects as performative definitions of sustainability: The case of food-waste-based biogas and biofertilizers. Journal of Material Culture, 21 (3), 383-401.

Dalmo, K.H., 2013. En norsk Maginotlinje? Forsvarets utbygging av permanente stillinger i Lyngen-området med vekt på Frøy-stillingene. Unpublished thesis (MA). Arctic University of Tromsø.

Drageset, A., Haugen, A.M. and Hesjedal, A., 2010. Arkeologiske undersøkelser i 2010 i forbindelse med Kv420 kraftlinje Balsfjord Hammerfest. Registreringer langs traseen i 
Troms: Balsfjord, Storfjord, Gaivuotna/Kåfjord, Nordreisa og Kvænangen kommuner. Befaringsrapport Kulturetaten - 2010. Troms fylkeskommune.

Eriksen, A. 2014., From Antiquities to Heritage. Transformations of Cultural Memory. Oslo: Berghahn.

Eriksen, T.H., 2016. Overheating: An Anthropology of Accelerated Change, London: Pluto Press.

Figenschau, I., 2016. Krigsminner som kulturminner: Redning eller klam omfavnelse? Primitive tider, 18, 199-215.

Fjermeros, H., 2013. Med lik i lasten. Operasjon Asfalt - de sovjetiske massegravenes skjebne $i$ Norge, Oslo: Scandinavian Academic Press.

Gaukstad, E., and Holme, J., 2001. Hovedaktørene i kulturminneforvaltningen. In: J. Holme, ed. Kulturminnevern. Lov, forvaltning, håndhevelse. Bind I. Oslo: Økokrim, 136-145.

Gierløff, C.W., et al., 2017. Verdien av kulturarv. En samfunnsøkonomisk analyse med utgangspunkt i kulturminner og kulturmiljøer. Menon Economics.

González-Ruibal, A., 2008. Time To Destroy: An Archaeology of Supermodernity. Current Anthropology, 49 (2), 247-279.

Harrison, R., 2013a. Forgetting to remember, remembering to forget: late modern heritage practices, sustainability and the "crisis" of accumulation of the past. International Journal of Heritage Studies, 19 (6), 579-595.

Harrison, R., 2013b. Heritage. Critical Approaches, London \& New York: Routledge.

Harrison, R., 2015. Beyond "Natural" and "Cultural" Heritage: Toward an Ontological Politics of Heritage in the Age of Anthropocene. Heritage \& Society, 8 (1), 24-42.

Heidegger, M., 1977. The Question Concerning Technology and Other Essays. New York: Harper \& Row.

Hesjedal, A. and Andreassen, D.-M., 2015. Kulturminneundersøkelser i 2015, Krigsminnelandskap Troms. Registreringer langs Lyngenlinja i Storfjord kommune. Befaringsrapport Kulturetaten - 2015. Unpublished report. Troms fylkeskommune.

Hult, A., 2017. Unpacking Swedish Sustainability. The promotion and circulation of sustainable urbanism. School of Architecture and the Built Environment, Department of Urban Planning and Environment. Stockholm: KTH Royal Institute of Technology.

Hunt, V., 2014., Fire and Ice. The Nazis' Scorched Earth Campaign in Norway, Gloucestershire: The History Press.

Introna, L.D., 2009. Ethics and the Speaking of Things. Theory, Culture \& Society, 26 (4), 25-46. 
Jaklin, A. 2006., Nordfronten. Hitlers skjebneområde. Trondheim: Gyldendal.

Jenney, E.R., 2014 [1945]. Undersøkelser av krigsforbrytelser i Skibotn- og Kvesmenesområdet. Utdrag av uformell rapport av E. Ross Jenney. Fra The National Archives, London. In: T. Figenschau, ed. Krigen i Storfjord. Mord, mytteri, krigsforbrytelser. Signaldalen: Tekst \& Cetera, 144-155.

Kahn, M., 2001. Automatisk fredete kulturminner: med særlig vekt på tiltakshaverens rolle i kulturminnevernet. Unpublished thesis. The Arctic University of Norway.

Kahn, M., 2007. Laerebok i kulturminnerett, Trondheim: Tapir akademisk forlag.

Laclau, E., 1990. New Reflections on The Revolution of Our Time. London: Verso.

Latour, B., 1987. Science in Action: How to Follow Scientiests and Engineers Through Society, Cambridge: Harvard University Press.

Lennon, J. and Foley, M., 2004. Dark Tourism. The Attraction of Death and Disaster, London: Thomson.

Lévi-Strauss, C., 1987. Introduction to the Work of Marcel Mauss, London: Routledge \& Kegan Paul.

Light, D., 2017. Progress in dark tourism and thanatourism research: An uneasy relationship with heritage tourism. Tourism Management, 61, 275-301.

Lund, G., 2014 [1982]. Tyske krigsforbrytelser i Storfjord: Dødsleiren i Kitdalen. In: Figenschau T (ed) Krigen i Storfjord. Mord, mytteri, krigsforbrytelser. Signaldalen: Tekst \& Cetera, 70-84.

MacDonald, S., 2006. Undesireable Heritage: Facist Material Culture and Historical Consciousness in Nuremberg. International Journal of Heritage Studies, 12 (1), 9-28.

Mann, C. and Jörgensen, C., 2016. Hitler's Arctic War. The German Campaigns in Norway, Finland and the USSR 1940-1945, Barnsley: Pen \& Sword Military.

Ministry of Environment, 1997. Miljøvernpolitikk for en borekraftig utvikling - Dugnad for framtida. St.meld. $n r .58$ (1996-97). [Environmental Protection for Sustainable Development - Voluntary Work for the Future. Report No. 58 to the Storting (199697).] Available from: https://www.regjeringen.no/no/dokumenter/st-meld-nr-58 199697/id191317/ [Accessed 27 February 2019].

Ministry of Environment, 2005. Leve med kulturminner. St.meld. nr. 16 (2004-2005). [Living with Cultural Heritage. Report No. 16 to the Storting (2004-2005).] Available from: https://www.regjeringen.no/no/dokumenter/stmeld-nr-16-2004-2005-/id406291/ [Accessed 27 February 2019].

Ministry of Environment, 2013. Fremtid med fotfeste. St.meld. $n r .35$ (2012-2013). [A Rooted Future. Report No. 35 to the Storting (2012-2013).] Available from: 
https://www.regjeringen.no/no/dokumenter/meld-st-35-20122013/id725021/

[Accessed 27 February 2019].

Moore, H.L., 2004. Global anxieties. Concept-metaphors and pre-theoretical commitments in anthropology. Anthropological Theory, 4 (1), 71-88.

Myrvoll, E.R., 2012. I vårt bilde? Landskap og kulturminner, verdi og forvaltning. Unpublished thesis. Arctic University of Norway.

Nilsen, G., 2003. Brytninger mellom lokal og akademisk kulturminnekunnskap. En analyse av fortidsforestillinger i Nord-Troms og Lofoten. Unpublished thesis. The Arctic University of Norway.

Olsen, B., 2013. Memory. In: P. Graves-Brown, R. Harrison and A. Piccini, eds. The Oxford Handbook of the Archaeology of the Contemporary World. Oxford: Oxford University Press, 204-218.

Olsen, B. and Pétursdóttir, P., 2016. Unruly Heritage: Tracing Legacies in the Anthropocene. Arkceologisk Forum, 35, 38-45.

Pétursdóttir, P., 2013. Concrete Matters. Towards an Archaeology of Things. Unpublished thesis. The Arctic University of Norway.

Pétursdóttir, P., and Olsen, B., 2014. An archaeology of ruins. In: P. Pétursdóttir and B. Olsen, eds. Ruin Memories. Materialities, Aesthetics and the Archaeology of the Recent Past. London \& New York: Routledge, 3-30.

Pool, J.L., 2016. Ruhetag: The Day-to-Day Life of the German Soldier in WWII. Volume II: Morale and Welfare, Atglen: Schiffer Publishing, Ltd.

Directorate for Cultural Heritage, 2015a. Fredningsstrategi mot 2020 for kulturminneforvaltningen. Available from: https://www.riksantikvaren.no/Fredning/Fredningsstrategi-mot-2020 [Accessed 5 November 2019].

Directorate for Cultural Heritage, 2015b. Vedlegg 1. Prioriterte tema til Fredningsstrategien bakgrunnsnotat. Available from: https://www.riksantikvaren.no/Fredning/Fredningsstrategi-mot-2020 [Accessed 5 November 2019].

Directorate for Cultural Heritage, 2015c. Informasjonsark. Krigens kulturminner. Available from: https://www.riksantikvaren.no/Ansvarsomraader/Krigens-kulturminner [Accessed 5 November 2019].

Samuels, J., 2015. Difficult Heritage. Coming “to Terms” with Sicily's Facist Past. In: K.L. Samuels and T. Rico, eds. Heritage Keywords. Rhetoric and Redescription in Cultural Heritage. Colorado: University Press of Colorado, 111-128. 
Seitsonen, O., 2018. Digging Hitler's Arctic War. Archaeologies and Heritage of the Second World War German Military Presence in Finnish Lappland. Department of Cultures. Helsinki: University of Helsinki.

Seitsonen, O., et al., 2017. A military camp in the middle of nowhere: mobilities, dislocation and the archaeology of a Second World War German military base in Finnish Lapland. Journal of Conflict Archaeology, 12 (1), 3-28.

Smith L., 2006. Uses of Heritage, London \& New York: Routledge.

Soleim, M.N., 2009. Sovjetiske krigsfanger i Norge 1941-1945. Antall, organisering og repatriering, Oslo: Scandinavian Academic Press/Spartacus.

UNESCO, 1972. Convention concerning the protection of the world cultural and natural heritage. Adopted by the General Conference at its seventeenth session Paris, 16 november 1972. Available from: https://whc.unesco.org/archive/convention-en.pdf [Accessed 27 February 2019].

UNESCO, 2011. Strategic Action Plan for the Implementation of the World Heritage Convention 2012-2020. Future of the World Heritage Convention. WHC11/18.GA/11, Paris. Available from: https://whc.unesco.org/archive/2011/whc1118ga-11-en.pdf [Accessed 27 February 2019].

US-Army, 1943. German Winter Warfare. Special Series. Washington: Military Intelligence Division, War Department.

WCED, 1987. Report of the World Commission on Environment and Development: Our Common Future. A/42/427. Available from: https://sustainabledevelopment.un.org/content/documents/5987our-common-future.pdf [Accessed 27 February 2019].

Young, K., 2009. Auschwitz-Birkenau. The challanges of heritage management following the Cold War. In: W. Logan and K. Reeves, eds. Places of Pain and Shame. Dealing with "Difficult Heritage”. New York: Routledge, Taylor \& Francis Group, 50-67.

\section{List of figures}

Fig. 1: Norddalen, Northern Norway. Part of the Lyngen Festung.

Fig. 2: Kitzbühel, June 1945. A single Finnenzelte still stands inside the POW camp. Photo: Bjørn Winsnes/Narviksenteret.

Fig. 3: Entangled presence: coke, rusty nails, reindeer lichen, wood, moss, iron, heather and buttons, some still attached to a German uniform. Photo: Ingar Figenschau.

Fig. 4: POW-camp Kitzbühel, august 2016. The remains of the tents can be seen as circular structures. Photo: Ingar Figenschau.

Fig. 5: A humble imprint of war. Photo: Ingar Figenschau.

Fig. 4: Everyday tools, everyday atrocities. The tools of the Lyngen Festung. Photo: Ingar Figenschau. 